Endocrinol. Japon., Vol. 3, No. 2 (1956)

\title{
THE EFFECT OF GOITROGENS ON THE HYPOTHALAMIC NEUROSEGRETION IN EXPERIMENTAL ANIMALS
}

\author{
KISHUO SHIBUSAWA, SUMIO SAITO, KAHEI NISHI, \\ TAKANOBU YAMAMOTO, CHIAKI ABE \\ AND KAORU TOMIZAWA
}

\author{
Department of Surgery, School of Medicine, Gunma University, Maebashi
}

Neurosecrets such as vasopressin and oxytocin are believed to be involved in the mechanism(s) of the release of pituitary ACTH and gonadotrophin, respectively (Shibusawa, 1955); and it is well accepted that the thyroid gland is under the control of the pituitary. Only scant attention has, however, been paid on the relation of the hypothalamus to the pituitary-thyroidal function. In terms of hypothalamic lesions, a few investigators have studied the structural alterations in the thyroid or pituitary gland (Greer, 1952, 1955; Scharf, 1955; Martini, 1955). Greer $(1952,1955)$ reported that the thyroidal response to exogenous thyrotrophin is changed in rats with anterior hypothalamic lesions.

We have suggested the possibility of a hypothalamic humoral control of the thyrotroph-thyroidal function in the preceding volume of this Journal (Shibusawa et al., 1955).

The present experiment was designed in the hope of elucidating the role of neurosecretory phenomenon in causing the hyper- and hypo-functions of the thyroid.

\section{MATERIALS AND METHODS}

Young adult male albino rats weighing $150-200 \mathrm{~g}$ and mongrel dogs weighing $15-18 \mathrm{~kg}$ were used. They were maintained in good environments as reported previously. Experimental animals were divided into groups receiving 1) methylthiouracil (MTU) alone; 2) MTU plus chlorpromazine ; 3) potassium iodide ; 4) thyroidectomy and 5) chlorpromazine alone. MTU $50 \mathrm{mg}$, chlorpromazine $10 \mathrm{mg}$, and potassium iodide $0.1 \mathrm{~g}$ per $\mathrm{kg}$ weight were injected subcutaneously twice daily for two or three weeks. Thyroidectomized dogs were examined two or three weeks after the operation.

The neurosecrets of the hypothalamic nerve cells were stained by the Bargmann's modification of Gomori's chromium alum haematoxylin-phloxin and Gomori's aldehyde-fuchsin methods. Anterior pituitary cells were stained with haematoxylin-eosin (H.E.), Azan, and periodic acidSchiff (PAS) techniques.

\section{RESULTS}

\section{Methylthiouracil group}

The administration of methylthiouracil produces enlargement of the thyroid and increases the thyroidal weight, and thyrotrophin (TSH) level in blood as reported by us in the preceding volume of this Journal.

Received for publication July 31, 1956. 
Histologically, the epithelial cells of the thyroid gland showed the hyperplasia and hypertrophy. Follicular colloid concentration was reduced sometımes (Fig. 1). In some follicles, epithelial cells showed adenoma-like structures. Cytological changes of the adenohypophysis were much more interesting. The so-called thyrotrophs beta cell of Halmi showed definite hypertrophy and gamma $(\gamma)$ cells, which are called chromophobe, were translated to beta-cell type (Fig. 2). In the PAS staining, there was an accumulation of coarser glycoprotein granules and/or leaned to one side. These changes seem likely to coincide with the hyperfunction of thyrotrophs. Changes of the hypothalamic neurosecretory cells were most remarkable. Nerve celles of Nucleus paraventricularis and Nucleus supraopticus released the gomoriphil substances and contained few granules (Fig. 3). Hypertrophy and mitosis of the nucleus, vacuolisation of cytoplasma, and eccentric position of nucleoli were the marked changes. These changes seem to show the hyperactivity of the hypothalamic neurosecretory system.

\section{Potassium iodide group}

Thyroidal epithelium cells were flat and almost like those in the control group. Variable size of follicles contained dense colloids and marginal vacuoles were seen (Fig. 4). Adenohypophyseal cells contained dense granules and thyrotrophic beta cells (Halmi, 1951) richly held PAS-positive granules (Fig. 5). The cells of Ncl. supraopticus and paraventricularis abundantly stored gomoriphil granules (Fig. 6). These changes seem to indicate the suppressing state of the hypothalamic and thyrotrophic-thyroidal system.

\section{MTU plus chlorpromazine group}

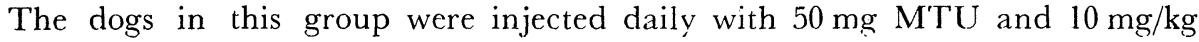
weight chlorpromazine for 3 weeks.

Thyroid gland showed no remarkable changes. Neither increase in thyroidal weight nor elevation of hypothalamic neurosecretory function were found (Fig. 7). In the adenohypophysis, there were a few beta cells, contrasting to the increase of the alpha $(\alpha)$ cells. In a beta cell, nucleus was picnotic and irregular. Outside the cells and intralobular spaces, aniline blue-positive granules were seen (Fig. 8). These changes were thought to be similar with one of pituitary stalksectioned dogs.

\section{Thyroidectomized group}

After thyroidectomy, a special type of adenohypophyseal cell was found two or three weeks later. This cell is called the thyroidectomy cell (Satwornitzkaja, 1926). We examined the thyroidectomized dogs 3 or 4 weeks after surgery. Anterior pituitary showed the typical thyroidectomy cell which was stained both by Azan and PAS methods (Fig. 9). In the hypothalamus, Ncl. paraventricularis and $\mathrm{Ncl}$. supraopticus showed releasing of their gomoriphil substances and hyperactivity (Fig. 10). These changes resembled to those in the methylthiouracil group. From these results, MTU or thyroidectomy is able to stimulate the hypothalamicthyrotroph-thyroidal system, and potassium iodide or chlorpromazine to inhibit the elevation of this system. 


\section{COMMENT}

The regulatory significance of the pituitary on the thyroid gland is beyond any doubt. By manifold investigations, the secretion of thyroid gland is proved to be controlled by the anterior lobe of the hypophysis. Li et al. (1955) reported, recently, the changes of the thyroid functions following hypophysectomy in man; and Dent, Gadsden and Furth (1956) examined the thyrotrophic-thyroidal functions in mice bearing pituitary thyrotrophin-producing tumors. Russfield (1955) examined histological changes of human hypophysis in various disease of the thyroid.

Greer (1955) stated that growth and function of the gland do not run parallel and that both processes may be separated from one another under experimental conditions. Scharf (1955) seems to agree with this view in terms of thermoregulation. They therefore assumed that two factors will be produced by the pituitary; a metabolic factor for the regulation of the thyroxin synthesis, and the other a growth factor for the proliferation of the thyroid gland. Grecr (1956) demonstrated in rats with anterior hypothalamic lesions that the thyroids proliferate by the administration of thyrotrophin. Bogdanove et al. (1955) made further observations on the pituitary structure and function in rats bearing hypothalamic lesions; and Ganong et al. (1955) proved the effect of hypothalamic lesions on thyroidal function in the dog. Thus, the growth of the thyroid or the pituitary secretion of the thyroproliferin (growth factor) seems to be under a humoral control of the anterior hypothalamus. Propylthiouracil (PTU) or methylthiouracil (MTU) is considered to reduce the synthesis and secretion of thyroxine in the thyroid gland. Our experiments with MTU showed that the thyroid gland proliferated simultaneously, and that hypertrophic basophil cells appeared in the adenohypophysis, and that the number and size of thyrotroph cells increased. In the anterior hypothalamus, Nucleus paraventricularis and Nucleus supraopticus showed marked reduction in gomoriphil substances and increase in cellular activity. Along the tractus supraoptico-paraventriculo-hypophyseus, the gomoriphil substances disappeared rapidly and completely, and bulb-shaped nerve endings appeared richly, leaving a few small Hering bodies. Further, the increased neurosecretion was not associated with the secretion of vasopressin and/or oxytocin. These observations agreed with our previously reported results, namely, the hypothalamic control of the thyrotroph-thyroidal function (Shibusawa et al., 1956). Present reports revealed the increase in the thyroidal weight, proliferation of the parenchymatous cells, and the augmentation of the hypothalamic neurosecretion with the prolonged administration of MTU and in the thyroidectomized dogs.

On the contrary, potassium iodide and chlorpromazine were found to inhibit the hypothalamic-thyrotroph-thyroidal functions. Martini (1955) reported the effects of PTU in rats and described the thyroidal hyperplasia accompanied by the increase in size, number, and cytologic activity of the basophilic cells of the hypophysis, and a marked increase in TSH concentration in the blood serum.

We were able to confirm his findings, and results seem to indicate that the source of thyrotrophin is in the basophilic cells of the hypophysis and that thyroid hyperplasia is due to the elevated blood TSH levels. Thus, MTU or thyroidec- 
tomy was associated with the hyperactivity of the neurosecretory cells of the anterior hypothalamus, and potassium iodide or chlorpromazine with the reduced activity. From these results, the pituitary secretion of thyroproliferin (growth factor) looked like being controlled through the hypothalamic neurosecretory system.

\section{SUMMARY}

The weight of the thyroidal gland increased by the use of methylthiouracil and was inhibited by chlorpromazine in experimental animals. The administration of MTU provoked not only an enlargement of the thyroid gland, but aiso an elevation of neurosecretion of the hypothalamic neurosecretory system. Thyroidectomy produced the most remarkable changes of the hypothalamic neurosecretory system. Chlorpromazine inhibited the hypothalamic neurosecretion and depressed the release of pituitary thyrotrophin. Thus the effect of methylthiouracil, chlorpromazine, and potassium iodide on the thyroid gland appears to be mediated through the hypothalamic neurosecretory system.

\section{ACKNOWLEDGMENT}

We are grateful to Prof. Fujio Yoshimura of Tokyo Jikeikai Medical College for undertaking histological examination.

\section{REFERENCES}

Bogdanove, E. M. and N. S. Halmi (1953). Endocrinol. 53, 274.

Bogdanove, E. M., B. N. Spirtos and N. S. Halmi (1955). Endocrinol. 57, 302.

Dent, J. N., E. L. Gadsden and J. Furth (1956). Cancer Research 16, 171.

Ganong, W. F., D. S. Fredrickson and D. M. Hume (1955). Endocrinol. 57, 355.

Goldenberg, I. S., P. J. Rosenbaum and M. A. Hayes (1955). Ann. Surg. 142, 786.

Goldsmith, R. E. and M. L. Eisele (1956). J. Clin. Endocrinol. \& Metabol. 16, 130.

Greer, M. A. (1955). Endocrinol. 57, 755.

Greer, M. A., and H. L. Eywin (1956). Endocrinol. 58, 665.

Guillemin, R. and B. Rosenberg (1955). Endocrinol. 57, 599.

Halmi, N. S., B. N. Spirtos and R. G. Stuelke (1954). Endocrinol. 57, 502.

Igel, H. (1955). Acta Endocrinol. 18, 455.

Kracht, J. and M. Spalthe (1953). Virchows Arch. 324, 83.

Krigge, K. M. (1955). Anat. Rec. 122, 295.

Martini, L. (1955). Arch. intern. Pharmacodyn. 101, 68.

Li, M. C., J. E. Rall., J. P. MacLean, M. B. Lipsett, B. S. Ray and O. H. Pearson (1955). J. Clin. Endocrinol. \& Metabol. 15, 1228.

Russfield, A. B. (1955). J. Clin. Endocrinol. Eீ Metabol. 15, 1393.

Scharf, J. H. (1955). Acta Neuroveg. 11, 100.

Schaumkell, K. W. (1955). Arch. exp. Path. Pharmakol. 225, 381.

Shibusawa, K., S. Saito, M. Fukuda, T. Kawai and F. Yoshimura (1955). Endocrinol. Japon. 2, 47.

Shibusawa, K., S. Saito, M. Fukuda, T. Kawai, H. Yamada and K. Tomizawa (1955). Endocrinol. Japon. 2, 182.

Shibusawa, K., S. Saito, K. Nishi, T. Yamamoto, K. Tomizawa and C. Abe (1956). Endocrinol. Japon. 3, (In press)

Wasserman, R. H., B. F. Trum, R. A. Monroe, J. J. Kane and C. L. Comor (1956). Am. J. Veterinary Res. 17, 149. 

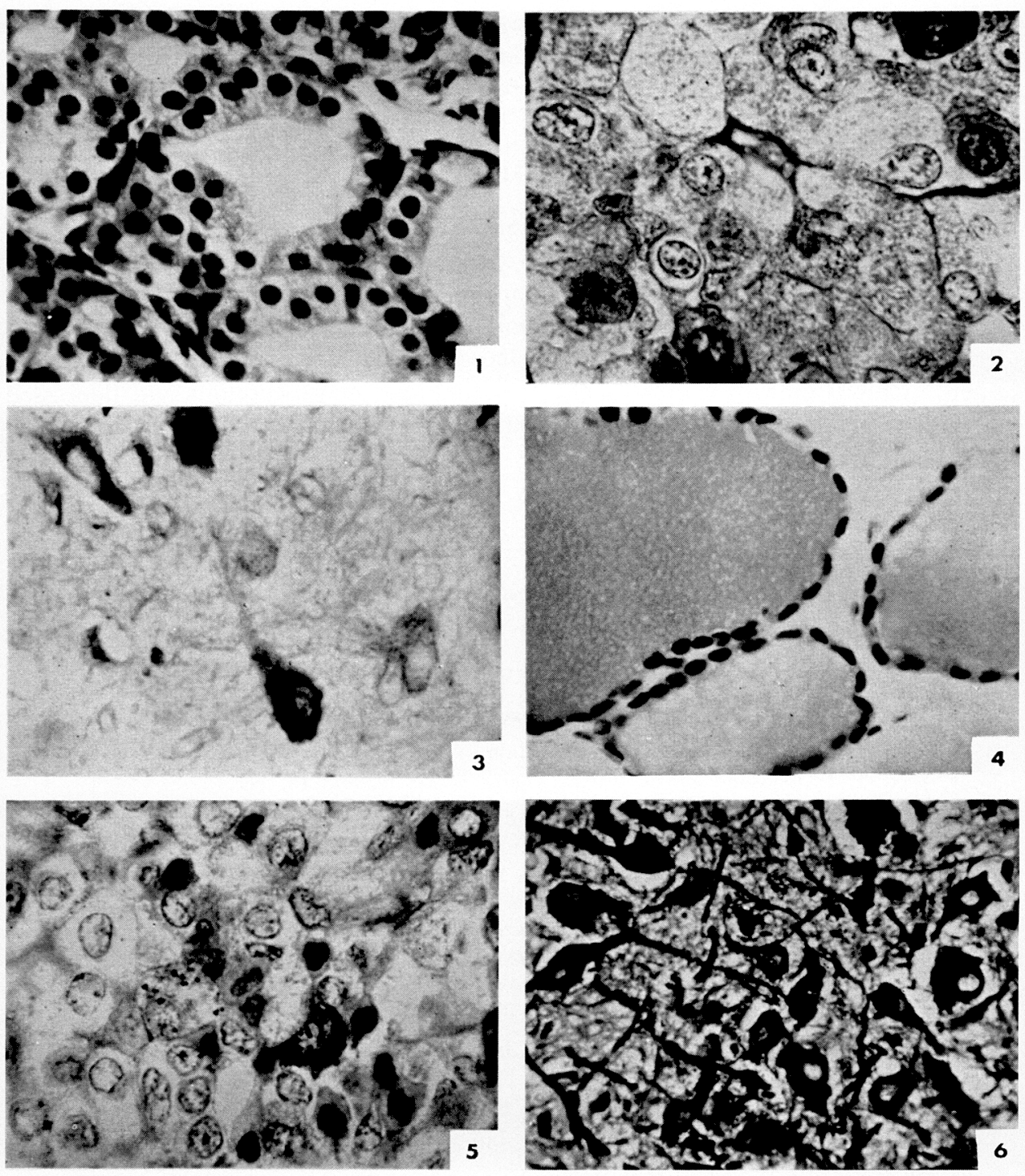

Fig. 1. Thyroid gland, methylthiouracil (MTU) $50 \mathrm{mg} / \mathrm{kg}$ daily for 3 weeks. (H. E. $\times 840$ ).

Fig. 2. Adenohypophysis, MTU-injected dog. Beta $(\beta)$ cell hypertrophy and translating type of $\gamma$ cell to $\beta$ form. (Azan staining $\times 1250$ ).

Fig. 3. Nel. supraopticus containing few granules, shows the hyperfunction. (Gomori's staining $\times 610)$.

Fig. 4. Thyroid gland, potassium iodide $0.1 \mathrm{~g} / \mathrm{kg}$ daily for 3 weeks. (H. E. $\times 840$ ).

Fig. 5. Adenohypophysis, $\beta$ cells containing PAS positive granules abundantly. (PAS staining $\times 1200)$.

Fig. 6. Ncl. paraventricularis, stored the gomoriphil granules. $(\times 540)$. 

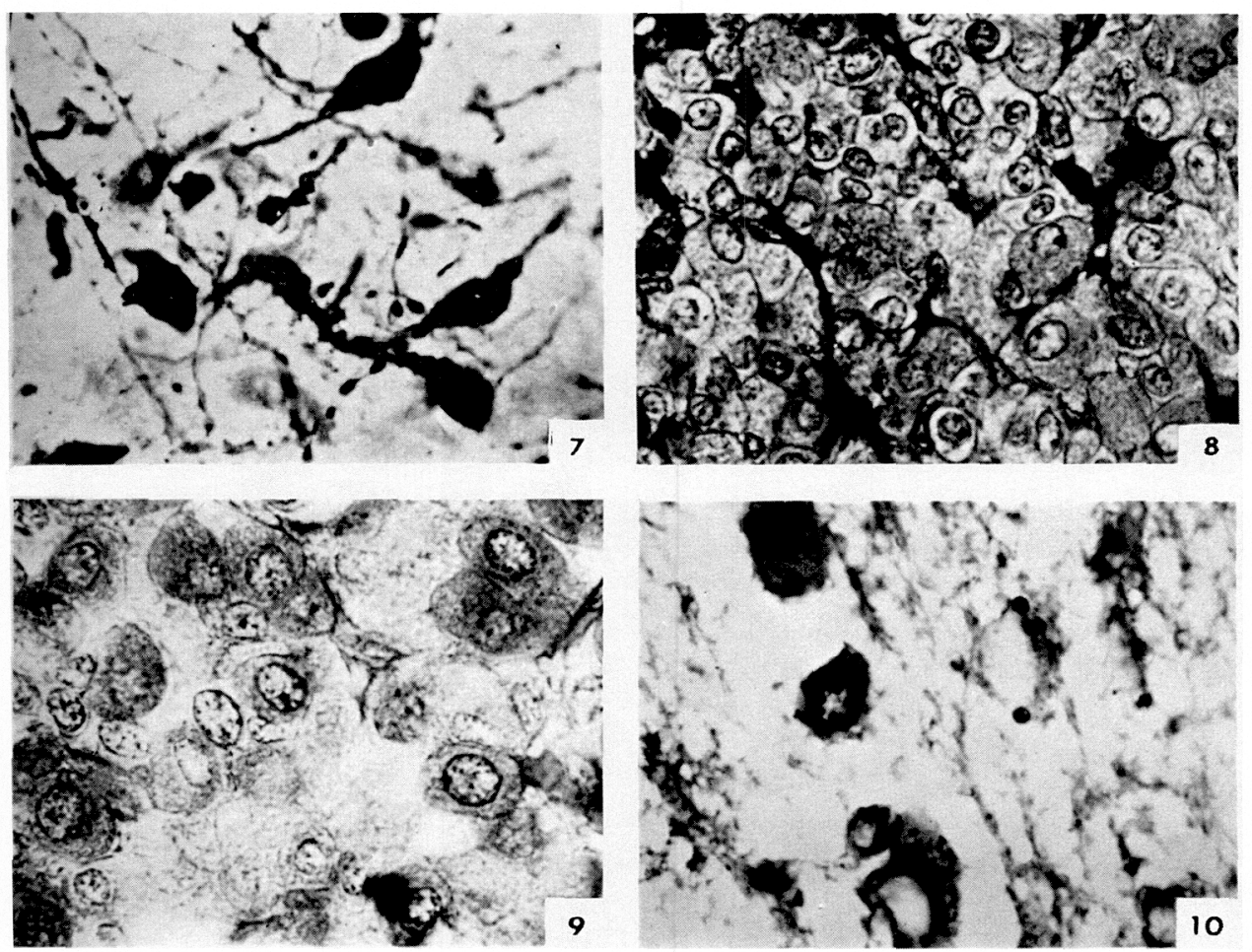

Fig. 7. Nel. paraventricularis, MTU plus chlorpromazine-injected group. Elevation of neurosecretory function is not found. $(\times 610)$.

Fig. 8. Adenohypophysis, a small number of $\beta$ cells containing picnotic nucleus, aniline blue-stained granules are seen in intralobular spaces. ( $\times 840)$

Fig. 9. Adenohypophysis, thyroidectomy cells are found remarkably. (PAS staining $\times 1250$ ).

Fig. 10. Ncl. supraopticus, gomoriphil substances are released from the nerve cells. Elevation of neurosecretory activity. $(\times 610)$. 